\title{
THE IMPACT OF CHILD HEALTH AND FAMILY INPUTS ON CHILD COGNITIVE DEVELOPMENT
}

\author{
Robert Kaestner \\ Hope Corman
}

Working Paper 5257

\section{NATIONAL BUREAU OF ECONOMIC RESEARCH 1050 Massachusetts Avenue \\ Cambridge, MA 02138 \\ September 1995}

This paper is part of NBER's research program in Health Economics. Any opinions expressed are those of the authors and not those of the National Bureau of Economic Research.

(C) 1995 by Robert Kaestner and Hope Corman. All rights reserved. Short sections of text, not to exceed two paragraphs, may be quoted without explicit permission provided that full credit, including $\odot$ notice, is given to the source. 


\title{
THE IMPACT OF CHILD HEALTH \\ AND FAMILY INPUTS ON CHILD \\ COGNITIVE DEVELOPMENT
}

\begin{abstract}
In this paper we extensively analyze the impact of child health and other family characteristics on the cognitive achievement of children between the ages of five and nine. We estimate both cross sectional and fixed effects models using data from the National Longitudinal Survey of Youth. Several of our results challenge the conclusions found in the existing literature. First, we find only a weak relationship between several measures of child health and child cognitive development. Second, we find that additional maternal schooling does not improve child cognitive achievement. Finally, our estimates of the effect of mother's labor force participation suggest that working has a positive impact on child cognitive achievement.
\end{abstract}

Robert Kaestner

School of Public Affairs

Baruch College

17 Lexington Avenue, Box 227a

New York, NY 10010

and NBER
Hope Corman

Department of Economics

Rider University

Lawrenceville, NJ 08648

and NBER 


\section{Introduction}

It is generally acknowledged that the health and intellectual development of children are largely determined by their family characteristics and individual endowments. Researchers from a variety of disciplines have produced a number of studies that have measured the impact of such factors as family income, household composition, and parental education on a variety of measures of child well being. Most research, however, has failed to examine the causal link between child outcomes. In particular, there is very little research that examines the effect of child health on child cognitive development, and most of the studies that do address this question treat it as a secondary issue.

Whether or not child health affects child cognitive development is an important area of research because of the key role that child cognitive development plays in determining a variety of social and economic outcomes. First, child cognitive achievement is a significant component of child quality, and as such, it is a source of parental and marital satisfaction. Therefore, factors that affect child cognitive achievement may also affect marital satisfaction and family structure. ${ }^{1}$ Second, there may be a significant externality associated with the production of child cognitive development if interactions among children are an important source of learning and development. Under such circumstances, one child's intellectual development will positively affect the cognitive development of other children with whom the child has contact. Thus, factors that influence individual cognitive development may also influence group cognitive development. Finally, and most importantly, child cognitive achievement has been shown to be positively related to later educational outcomes. ${ }^{2}$ Therefore, child cognitive development is an important determinant of individual and aggregate economic success. If child health adversely affects child cognitive achievement,

1 In a paper that examines the effect of child health on family structure, Corman and Kaestner (1992) found that a mother with a sick child is more likely to be observed in either a divorced or never married state than similar mothers with a healthy child.

${ }^{2}$ See the monograph by Lazar and Darlington (1982) for evidence related to the link between child and adult educational outcomes. 
public and private programs aimed at insuring adequate child health may be an important way of investing in the future.

The purpose of this paper is to estimate the impact of child health and family inputs on child cognitive development. In particular, we are interested in testing whether there is a significant relationship between a child's health status and their score on various cognitive achievement tests, holding constant other family inputs. To accomplish this goal, we use a variety of measures of child health in the analysis that cover both severe health conditions, and more commonly occurring health problems. Thus, this paper will provide the most comprehensive analysis to date of the effects of child health on child cognitive development.

In addition to examining the effects of child health on child cognitive development, we also re-examine the relationship between child cognitive development and other family inputs such as mother's time. Our contribution to this strand of the literature is primarily methodological. We estimate a fixed effect model using data on child cognitive achievement scores at two points in time. The individual fixed effect methodology allows us to control for unobserved endowments in a more complete way than prior studies and should result in improved estimates of the effects of family inputs on child cognitive development. ${ }^{3}$

\section{Previous Research}

There have been several previous studies examining the factors that influence child cognitive development, and Hanushek (1986) and the Congressional Budget Office (1987) provide excellent summaries of this earlier work. Only a few previous studies, however, include measures of child health. ${ }^{4}$ Broman, Nichols and Kennedy (1975) found a positive

\footnotetext{
${ }^{3}$ Hanushek (1992) uses a methodology similar to the one used in this analysis. Instead of using first differences of cognitive achievement, as we do here, Hanushek estimates a "value added" model in which the lagged achievement score is included among the regressors. The two approaches are quite similar. Baker and Mott (1992) also use a similar methodology. They examine the change in cognitive achievement as a function of both the changes and levels of family characteristics.

${ }^{4}$ In our literature review, we focus on studies of children in the United States.
} 
relationship between anthropometric measures of health (e.g.'s, weight and head circumference) and IQ for a large sample of four year old children from the U.S. Collaborative Perinatal Project. Edwards and Grossman (1979) examine the effect of a variety of child health indicators (e.g.'s, weight, height, abnormalities) on the cognitive development of white children 6-11 years of age from cycle II of the Health Examination Survey (1963-1965). These authors find significant effects of child health on cognitive development in cross sectional analyses. Shakotko et al. (1981) use the longitudinal followup of the Health Examination Survey data used in Edwards and Grossman (1979), and investigate the possibility of a dynamic relationship between child health and child cognitive development. Shakotko et al. (1981) find a significant impact of child health on the school achievement of teens. In addition, these authors present evidence suggesting that the causality between child health and child cognitive development runs in both directions.

More recently, Blau and Grossberg (1992) use data from the National Longitudinal Survey of Youth (NLSY) to examine the effect of maternal labor supply on cognitive achievement. They also include the mother's evaluation of her child's current health in their model, but delete from their sample children with severe health problems. These authors find an insignificant negative impact of poor child health on the cognitive development of children aged three to four years old. Rosenzweig and Wolpin (1994) also use the NLSY and include the child's birth weight in an analysis of child cognitive development. They found a small and significant effect of birth weight on cognitive development for a sample of children between the ages of five and eight. Korenman, Miller and Sjaastad (1994) examine the cognitive achievement of children between the ages of three and twelve. They use data from the NLSY and find that anthropometric measures of child health (e.g., weight and height) are negatively related to cognitive achievement.

All of the previous studies represent careful attempts at identifying the impact of child health on child cognitive development, but all of these papers are open to criticism for one of a variety of reasons. We improve on these studies in a number of ways. First, we utilize longitudinal data and examine the determinants of changes in child cognitive achievement, as 
opposed to the level of child cognitive achievement. This empirical strategy controls for the effects of unobserved endowments on cognitive achievement in a more complete way than the previously noted studies. Second, we use an array of child health measures, including measures of severe illness, more common ailments and anthropometric measures of child health, whereas most of the previous studies used a single measure. Third, we use a sample of children first observed when they are between the ages of five and seven, and thus minimize the effects of variations in unobserved school environment. In addition, we examine the impact of child health on cognitive development for each of the three age groups. Finally, we test whether child health is an endogenous variable, since any observed relationship between child health and child cognitive development may be the result of greater cognitive development causing better health. While past research may have addressed these problems individually, our paper is the first to address all of these issues in a unified framework.

\section{Analytical Background}

The household production model of Becker (1965) provides a useful framework for analyzing family behavior (Becker 1981). The basic idea of the Becker theory is that an individual (family) derives satisfaction not from market produced goods, but through the consumption of goods produced at home using their own time and market goods as inputs. This framework has been fruitfully used by previous researchers to analyze the production and demand for child educational development. ${ }^{5}$

We present a simple static model to help motivate our analysis. We assume that the household has a utility function represented as follows;

$$
\mathrm{U}=\mathrm{U}(\mathrm{L}, \mathrm{H}, \mathrm{E}, \mathrm{X}) \text {, }
$$

5 The Becker model is the basic framework used by Leibowitz (1977), Edwards and Grossman (1979), Shakotko et. al. (1981), Hanushek (1979, 1992), Fleischer (1977), Blau and Grossberg (1992), Rosenzweig and Wolpin (1994) and Hill and O'Neill (1994) to analyze child cognitive development. 
where $\mathrm{L}$ is a vector of the household member's leisure time, $\mathrm{H}$ is a measure of the average health of all children in the family, $\mathrm{E}$ is a measure of average intellectual development (e.g. education) of all children in the family, and $\mathrm{X}$ is a vector of other consumption goods. ${ }^{6}$

Child health $\left(\mathrm{H}_{\mathrm{i}}\right)$ and intellectual development $\left(\mathrm{E}_{\mathrm{i}}\right)$ are produced according to the household production technologies given below:

(2) $H_{i}=f\left(L_{f}, E_{i}, Y ; H_{0}\right), \quad i=1, \ldots, n$

and,

(3) $\mathrm{E}_{\mathrm{i}}=\mathrm{g}\left(\mathrm{L}_{\mathrm{f}}, \mathrm{H}_{\mathrm{i}}, \mathrm{Z} ; \mathrm{E}_{0}\right)$.

We assume that only the mother's non-market time $\left(L_{f}\right)$ is used to produce child quality. Note also that child health enters the production function of child intellectual development, and child intellectual development is an input in the health production function. The variables $\mathrm{Y}$ and $\mathrm{Z}$ in equations (2) and (3) represent inputs into the production function, such as the quantity of medical care and educational resources purchased by the family for the production of child health and child education respectively. These goods do not yield any direct utility to the family. The variables $\mathrm{H}_{0}$ and $\mathrm{E}_{0}$ represent the health endowment and intellectual endowment of the child. The family maximizes utility subject to equation (2) and (3) and an income constraint.

Our primary interest is in estimating the parameters of the structural production function represented by equation (3), and in particular the impact of child health on intellectual development. An important point emphasized in the past literature is that income and prices do not enter the structural production function of child quality (e.g., education), but only enter the reduced form demand function. In most previous studies of child cognitive development, however, income has been included in the model to control for

\footnotetext{
6 Included among the goods in $\mathrm{X}$ is the quantity of children, and therefore, the utility function specified in equation (1) is consistent with the Becker and Lewis (1973) quantityquality model of children.
} 
differences in the amount of resources available to the household. A model that includes income along with the quantity of other production inputs has been labeled the "hybrid" model by Rosenzweig and Schultz (1983). As these authors demonstrate, the "hybrid" model will generally yield biased estimates of the effect of inputs on the production of child quality. Estimates of the effect of child health on cognitive development may also be biased, however, if important inputs affecting the production of child quality are omitted from the analysis. Family income may be a relatively good proxy variable for the omitted inputs, and since it is highly likely that we have omitted some relevant input, we have included income in the analysis.

\section{Empirical Issues}

Obtaining unbiased estimates of a structural production function similar to equation (3) is difficult for a variety of reasons. First, we assume that the child cognitive production function has a simple linear or log linear form. ${ }^{7}$ Thus, at time $t(t=0, . ., T)$ child cognitive achievement may be written as

$$
\mathrm{E}_{\mathrm{it}}=\mathrm{E}_{0}+\Sigma_{\mathrm{t}}\left(\alpha_{1 \mathrm{t}} \mathrm{L}_{\mathrm{ft}}+\alpha_{2 \mathrm{t}} \mathrm{H}_{\mathrm{it}}+\alpha_{3 \mathrm{t}} \mathrm{Z}_{\mathrm{it}}\right)+\nu_{\mathrm{it}},
$$

or

(5a) $\ln \mathrm{E}_{\mathrm{it}}=\ln \mathrm{E}_{0}+\Sigma_{\mathrm{t}}\left(\alpha_{\mathrm{it}} \mathrm{L}_{\mathrm{ft}}+\alpha_{2 \mathrm{t}} \mathrm{H}_{\mathrm{it}}+\alpha_{3 \mathrm{t}} \mathrm{Z}_{\mathrm{it}}\right)+\nu_{\mathrm{it}}$.

The production functions specified in equation (5) and (5a) are dependent on the child's intellectual endowment $\left(E_{0}\right)$, the cumulative amount of family inputs (e.g., $\left.L_{f}\right)$, and a set of time varying parameters $\left(\alpha_{\mathrm{i}}\right)$.

The most important problem related to estimating this model is the presence of the

7 The linear and log-linear form of the production function have been frequently used by researchers examining changes in cognitive achievement. These two functional forms have very different implications for the analysis of changes in cognitive achievement. Another frequently used functional form which we ignore is that in which changes in cognitive achievement depend on the initial level of achievement. Ragosa and Willett (1985) provide a review of a variety of empirical specifications of the cognitive production function. 
unobserved endowment. If other production inputs are correlated with the unobserved endowment, the parameter estimates of the model will be biased. More generally, since some of the other production inputs are also choice variables (e.g., $\mathrm{L}_{\mathrm{ft}}$ ), they may be endogenous to child health.

To overcome similar problems, previous researchers have used a variety of procedures. Olsen and Wolpin (1983) and Rosenzweig and Wolpin (1994) use a family fixed effect model in which sibling differences form the units of observation. This procedure accounts for the unobserved differences across families, but not across children, and thus, is only a partial solution to the heterogeneity problem. In addition, the family fixed effects model restricts the sample to families with at least two children. Rosenzweig (1986) and Rosenzweig and Wolpin (1988) use a "lagged instrumental fixed effect" model that makes use of data on siblings, as in the family fixed effect model, but instruments for endogenous inputs using variables suggested by information restrictions in their theoretical model. ${ }^{8}$ Hanushek (1992) uses a "value added" approach, which consists of analyzing current child achievement, holding constant previous achievement levels of the child. The Hanushek (1992) procedure accounts for both the family and individual effect, and is feasible as long as there is information on achievement at two points in time. In this regard, the "value added" approach is similar to a standard fixed effect methodology which takes first differences of individual data, except in the "value added" approach, prior achievement enters the model on the right hand side.

Since the NLSY contains information on child cognitive achievement at two points in time $(t=1,2)$, we use an individual fixed effect model. The fixed effect methodology applied to equations (5) and (5a) yields

\footnotetext{
The instruments for the endogenous production inputs used in this case are the lagged level of the inputs and the parental characteristics. The parental characteristics are appropriate instruments since the unobserved family effect has been eliminated by taking first differences of sibling data.
} 


$$
\mathrm{E}_{\mathrm{i} 2}-\mathrm{E}_{\mathrm{i} 1}=\alpha_{12} \mathrm{~L}_{\mathrm{i} 2}+\alpha_{22} \mathrm{H}_{\mathrm{i} 2}+\alpha_{32} \mathrm{Z}_{\mathrm{i} 2}+\nu_{\mathrm{i} 2}-\nu_{\mathrm{i} 1},
$$

and

(6a) $\ln \mathrm{E}_{\mathrm{i} 2}-\ln \mathrm{E}_{\mathrm{i} 1}=\alpha_{12} \mathrm{~L}_{\mathrm{i} 2}+\alpha_{22} \mathrm{H}_{\mathrm{i} 2}+\alpha_{32} \mathrm{Z}_{\mathrm{i} 2}+\nu_{\mathrm{i} 2}-\nu_{\mathrm{i} 1}$,

where everything is defined as before. In addition to being a good way to control for unobserved heterogeneity in the sample, the fixed effect methodology also reduces the amount of data necessary to estimate the model. Child cognitive development at any point in time depends on the entire history of production inputs and not simply current input levels (Hanushek 1992). For example, current child cognitive achievement will depend on the mother's time input in all prior periods. Indeed, Desai et al. (1989) present results indicating that it is the mother's time input in the year just after birth that affects the cognitive achievement of 4 year old children. The fixed effect methodology only requires data on the amount of inputs used between the two times that child cognitive achievement was measured.

The fixed effect methodology accounts for the statistical endogeneity of the regressors that arises due to the omitted endowment, but several of the regressors may still be endogenous as a result of the structural relationships between child cognitive development, child health and family inputs. For example, Shakotko et al. (1981) present evidence indicating that among teens, education (intelligence) is a significant determinant of health. Although it is less likely that cognitive development will affect the health of a child who is between five (seven) and seven (nine) years old, the possibility still exists. Perhaps as Shakotko et al. (1981) speculate, more intelligent children may be better at following instructions about medication and treatment, or be more inclined to understand the benefits associated with following parental advice about healthy behaviors (e.g., eating breakfast). On the other hand, at this age child health may primarily be a function of the health endowment and family resources and behavior.

We empirically test the exogeneity of the current child health measures by estimating a structural model using a two stage least squares (2SLS) procedure. As instruments for 
current child health, we use measures of the child's health endowment: a dummy variable indicating that the child's birth weight was less than 2500 grams, a dummy variable indicating that the child stayed in the hospital longer than the mother at the time of birth, and a dummy variable indicating that the child was admitted to the hospital in the first year after birth. The child health endowment should be correlated with current health, but uncorrelated with the change in cognitive development. As equations (5) and (5a) make clear, cognitive development at time $t$ depends on the child's health status in all previous periods. The change in cognitive development between time $t$ and $t+1$, however, depends only on the child's health status during the period between time $t$ and $t+1$. Thus, the child's health endowment does not enter the fixed effect model of child cognitive development, but it should be correlated with the child's health status during the period of interest.

In addition to child health, other right-hand side variables in equation (6) may also be (structurally) endogenous. While a plausible story may be made for why several of the variables used in the model may be endogenous, we will restrict our attention to only one additional variable, namely mother's time use. In the current data, mother's time use is measured as her weeks and hours of work, which implies that more time spent in the market comes at the expense of non-market home production time. The mother's time use may be a direct function of the intellectual development of the child, particularly since several inputs are unobserved by the researcher. For example, the quality of the school environment is unobserved, and the mother may adjust her time allocation in response to the progress, or lack of progress, the child is making in school. Thus, the mother's time use will depend on the child's cognitive achievement. ${ }^{9}$ The instruments used to predict mother's labor force participation are her prior attitude toward work outside the home and the county level unemployment rate. These variables are arguably appropriate instruments. The

9 Blau and Grossberg (1992) also treat the mother's time use as structurally endogenous and use a 2SLS procedure to address this issue. Test of exogeneity, however, fail to reject the null hypothesis that the mother's labor force participation is exogenous. Rosenzweig and Wolpin (1994) treat the mother's time allocation as statistically endogenous. They assume that after controlling for the unobserved endowment, mother's time allocation is exogenous. 
unemployment measures are demand side variables that affect labor force participation indirectly through wages and possibly directly if there are hours constraints. There is no reason to expect the unemployment rate to be a predictor of child cognitive achievement. The mother's view on work outside the home was measured 9 to 13 years prior to the child assessments, and is not expected to affect child cognitive achievement.

One disadvantage of the fixed effect methodology is that estimates of the effects of variables that don't change over time cannot be obtained. For example, the effect of mother's IQ, or innate ability, on child cognitive achievement cannot be estimated using a fixed effect methodology. Similarly, the effects of the early childhood home environment, preschool attendance, and endowed child health cannot be estimated. Thus, the fixed effects

methodology restricts the number of issues that can be examined, although it is an effective way to control for unobserved endowments. Since most of the past research has not used the fixed effects approach, our study represents an important contribution to the literature.

\section{Data}

The data we use in this paper comes from the youth cohort of the National Longitudinal Survey of Labor Market Experiences (NLSY). The NLSY is a national probability sample of young adults who were between the ages of 14-21 in 1979, the first year of the survey (Center for Human Resources 1994). The respondents have been interviewed on a yearly basis since that time. The data contain detailed information about the respondent on the following subjects: marital history, schooling, labor force experience, health, fertility, child rearing practices and geographic mobility. In 1986, 1988, 1990, and 1992 a variety of child assessments were administered to all children born to the respondents by those dates. The assessments were age specific, and encompass cognitive, socioemotional and physiological aspects of child development.

The NLSY is an excellent data source for our purposes. It contains information about child cognitive development, child health, and the family characteristics of interest. In addition, it is a longitudinal data set containing detailed information on a variety of other 
factors that will be used as control variables in the analyses. There are, however, some deficiencies in the data. The most important is that the sample consists of relatively young women and their children. In 1992 the oldest respondent is 34 years old, and is therefore not representative of all families with children. Another disadvantage of the NLSY is that the child health measures are predominantly self reported by the mother and may embody a substantial amount of measurement error.

The principal goal of this paper is to examine the effects of child health on child cognitive development. As was noted above, due to the problem of unobserved heterogeneity, it is necessary to have measures of cognitive achievement at two points in time which will allow for the implementation of a fixed effect estimation procedure. This criterion necessitates that the youngest children we are able to include in the sample are those who are at least five years of age. At age five, the children first take the Peabody Individual Achievement Tests (PIAT's), and the PIAT's are administered to all age eligible children in each of the assessment years $(1986,1988,1990$ and 1992). Thus, there is a longitudinal record of the children's score on the same cognitive achievement test only for those children who reach age five by 1990 . We focus on the group of children who are between the ages of five (seven) and seven (nine) and examine the change in test scores over a two year period.

There are three components of the PIAT's: reading recognition, reading comprehension, and math. The test instruments are the same for all children, and thus the raw score on the test increases in absolute value over time as the child ages and is able to answer more of the questions correctly. For example, the math test consists of 84 multiple choice questions beginning with recognizing numerals and progressing to trigonometry. Children can select the answer by pointing to or naming their choice (Center for Human Resources 1993). The PIAT is a widely used assessment of cognitive ability and academic achievement, and has been found to be a reliable and valid measure of various aspects of 
child cognitive development. ${ }^{10}$

In our analysis we use the reading recognition and math components of the PIAT's, and we exclude all children whose mother identify their ethnic background as Hispanic. The Hispanic children are excluded to avoid confounding proficiency in the English language with cognitive achievement. The PIAT reading recognition test measures word recognition and pronunciation ability. The PIAT math test measures the child's attainment in mathematics as taught in mainstream education. The final sample size is approximately 2300 children.

The key explanatory variable of interest is child health and we measure it in several ways that cover both serious and common illnesses. We use three variables that proxy for the child's health endowment: birth weight, a dummy variable indicating that the child stayed in the hospital longer than the mother at the time of birth, and a dummy variable indicating that the child was admitted to the hospital during their first year of life. Our measures of recent child health include: a dummy variable indicating whether the child has had a condition that limits activity or that requires treatment by a physician in the last 12 months, the number of illnesses in the previous twelve months, a dummy variable indicating the presence of a serious illness (asthma, respiratory disorder, orthopedic handicap, heart trouble, and chronic nervous disorder), a dummy variable indicating whether the child is below the 10th (25th) percentile for weight, a dummy variable indicating that the child was below the 10th (25th) percentile for height, and a dummy variable indicating that the child was below the 10th (25th) percentile for body mass index (weight/height ${ }^{2}$ ). The standards used to derive the anthropometric measures come from cycle I and II of National Health and Nutrition Examination Survey (Frisancho 1990).

Our measures of child health are less than ideal. First, most of the child health measures are subjective and depend on the accuracy of the mother's reporting. Only the anthropometric measures are actual measurements (tape and scale), and only for

10 See Baker et al. (1993) for a complete description of the cognitive tests administered to the children in the NLSY. 
approximately 50 percent of the observations. ${ }^{11}$ Second, the fixed effect methodology requires measurements of inputs between assessments, but in most cases we have measures that pertain to the previous year (e.g., number of illnesses), or are current measures (e.g., height and weight).

In addition to the child health measures, other variables included in the model consist of child demographic variables, characteristics of the county of residence and variables that measure changes in family attributes that take place during the approximately two year interval between cognitive assessments. The area specific measures are included to measure differences in school quality and the family characteristics are proxy variables for family inputs. Measuring only the amount of inputs that were available during this period is consistent with the fixed effects approach which is the primary method of analysis that will be used. These variables include measures of parental resources such as the proportion of weeks worked by the mother, the average hours per week the mother works, the proportion of time spent in a single family household, average family income, the proportion of time the family received AFDC, changes in the number of children in the family, and whether the mother attended school during the period.

As noted above, if there are important production inputs that are unmeasured and therefore not included in the model, an income variable may be a partial solution to this specification problem since income is expected to be positively related to input levels. Average real family income is measured as a three year average in an attempt to measure a more permanent level of income. ${ }^{12}$ The appendix contains a complete list of variable definitions, means and standard deviations.

11 Miller and Korenman (1994) compare the height and weight reported by mothers to those obtained through measurement. They report that the reported weight and height exhibit a pattern of "heaping" at five pound intervals and at six inch intervals for weight and height respectively. More importantly, however, they found no significant difference in the mean weight and height between the two groups.

12 The CPI is used to deflate all income measures. If income is missing in a year, the two year average is calculated and used. If income is missing in more than one year, we set average income to zero and include a dummy variable indicating that income is missing. 


\section{Estimation and Results}

The empirical analysis is presented in two stages. First, cross sectional results are presented which examine the level of cognitive achievement of children between the ages of seven and nine. This analysis will provide a link to several past studies which estimate cross sectional analyses, and will also provide a basis for evaluating the relative contribution of the child specific endowment to cognitive achievement. The second analysis that we present is an examination of changes in child cognitive achievement over an approximately two year period for children between the ages of five (seven) and seven (nine). In these analyses, child health and mother's labor force participation will be treated as exogenous variables. We also experiment with an instrumental variables (IV) procedures in which we treat child health and mother's labor force participation as endogenous.

\section{A. Cross Sectional Estimates}

Tables 1 and 2 present the cross sectional results. Table 1 lists the results from a model that assumes the child cognitive production function takes on a linear form, and Table 2 lists the results under the assumption that the child cognitive production function is loglinear. For each of the three age groups in the sample, 20 separate models were estimated and differ according to which PIAT (reading or math) is the dependent variable, and which measure of child health is included among the regressors. Estimates from a model in which the three age groups were pooled are also presented, although F-tests of the restrictions imposed by pooling the data rejected the validity of pooling. ${ }^{13}$ All of the estimates associated with the child health measures are included in Tables 1 and 2. A complete set of estimates for several representative models are listed in Table 3.

Note that several of the variables (child age, number of siblings, mother's age and

13 Note that many previous studies pool the data for children of different ages. This may lead to incorrect inferences regarding the impact of child health and other variables on cognitive development. An F-test rejected the validity of pooling the data even when separate intercepts for age of child and interactions between the age dummies and a continuous measure of age were included in the model. 
education, and county characteristics) included in the cross sectional analyses are measured at the time of assessment and are expressed in levels. For example, mother's education is measured as the number of years of completed education at the time the cognitive achievement test was administered. In the fixed effect analysis, the corresponding measure for this variable is the change in mother's education. Most of the variables, however, are measured in the same way in the cross sectional and fixed effect analyses since it appeared reasonable to include many of the same variables in both models. In instances where it seemed illogical to include in the cross sectional model, a variable constructed for a fixed effect procedure, a new variable was defined.

The estimates of the effect of the child health variables on cognitive achievement are in most cases negative (positive for birth weight), but approximately two thirds are statistically insignificant. The anthropometric measures of child health, particularly weight and height, tend to have the most consistent effects. Very thin and very short children tend to have lower achievement test scores than heavier and taller children. This observation is particularly true for children age seven and for the PIAT math test for children of other ages. The magnitudes of the effect of the anthropometric measures are relatively small. For example, the largest effect listed in Table 1 is -4.848 , the effect on a seven year old child's PIAT math test score of being below the 10th percentile for weight. This effect is equivalent to .5 standard deviations in the math test scores of children aged seven.

For the other measures of child health, there are relatively few significant effects and most of these are observed among the estimates for the sample of children age seven. Children age seven who have medical conditions that limit activity or require medical attention, or who had a serious illness, have lower PIAT math test scores. A child's birth weight is also a significant predictor of achievement test scores for children age seven, although this effect is very small. For example, the estimates in Table 2 indicate that one pound increase in birth weight raises test scores approximately 3.2 percent.

The estimates in Tables 1 and 2 provide only weak evidence that child health adversely affects child cognitive achievement. The strongest evidence of an adverse effect 
are the estimates of the effect of being very thin or very short. There is, however, an alternative explanation of these results that needs to be discussed. Miller and Korenman (1994) show that long term poverty significantly increases a child's chances of being nutritionally disadvantaged. Thus, the negative effects on cognitive achievement of being very thin or very short may be confounded with poverty. This alternative explanation is probably not correct for two reasons. First, we include several variables in the regression model that should be good proxies for poverty including family income, the proportion of time in the last two years family has been on AFDC, family structure over the past two years and mother's education. Second, Korenman et al. (1994) show that estimates of the effect of anthropometric measures of child health on cognitive achievement are negative and significant even after explicitly controlling for long term poverty status.

The estimates in Tables 1 and 2 are somewhat consistent with those found in previous research, but weaker and less robust. For example, Edwards and Grossman (1979) found that child's birth weight, height and presence of illness (abnormality) are all significant predictors of child intelligence. Rosenzweig and Wolpin (1994) found that birth weight has a significant effect on child cognitive achievement. Finally, Korenman et al. (1994) found that birth weight and current height and weight were negatively related to child achievement test scores. In our results birth weight is significant only among the sample of children age seven, and the measures of current height and weight are significant mainly with respect to the PIAT math test. Our generally weaker findings may be due to differences in methodology and samples. Rosenzweig and Wolpin (1994) use the NLSY and estimate a family fixed effect model using a sample of families with young mothers with at least two children. Edwards and Grossman (1979) use a sample of older children (6-11) and objective measures of child health. Korenman et al. (1994) use the NLSY and normed percentile test scores. In all of these studies, children of different ages were pooled. The pooled results listed in Tables 1 and 2 provide more consistent evidence that child health adversely affects child cognitive achievement, but as noted above, the restrictions imposed by pooling the age groups were rejected by standard statistical tests. 
Table 3 provides a full set of regression results for a model that uses the PIAT reading score as the dependent variable and the presence of a medical condition as a measure of child health. The estimates associated with the non-health variables listed in Table 3 are for the most part consistent with the results found in many previous studies and expectations regarding how these variables should affect child cognitive achievement. Child's age is positively and significantly related to child cognitive achievement, and the race dummy is negatively related to cognitive achievement. The race dummy may be a proxy for unobserved differences in family resources. Note that the dummy variable indicating a female child is usually positive and significant, and that the dummy variable indicating a black female child is not different than zero. These results are consistent with the hypothesis that female children develop faster than male children, and that race is a proxy for unobserved family inputs. Thus, the faster development of black female children relative to white male children offsets the disadvantages associated with lesser black family resources.

Several of the family characteristics are also significantly related to child cognitive achievement. The effect of mother's education on child cognitive achievement is always positive and significant, and the number of brothers and sisters in the family is usually negatively related to cognitive achievement. Mother's age is largely uncorrelated with child cognitive achievement. The estimate associated with the percent of time the family received AFDC in the past two years implies that the cognitive achievement of children from AFDC families is on average lower than the achievement of children from families that did not receive AFDC.

The estimates of the effect of mother's labor force participation on child cognitive achievement are surprising. The coefficient on the proportion of weeks the mother worked in the past two years is always positive and usually significant, suggesting that working not only doesn't impede child cognitive development, but actually improves it. This conclusion is qualified by the estimates associated with the other two labor supply measures, the average hours worked per week and the interaction of weeks and hours, both of which are always negative. The marginal effect of labor force participation, however, remains positive over a 
wide range of hours (e.g., approximately 45 hours using the estimates in Table 3).

Finally, the estimates in Table 3 indicate that family structure (i.e., marital status) and family income are not significantly related to child cognitive achievement. Per capita income in the county where the child resides, however, has a positive effect on achievement.

Children from counties with high incomes have higher test scores. This effect may measure the quality of the schools or be correlated with unobserved individual and family characteristics that affect child cognitive development.

\section{B. Fixed Effect Estimates}

The estimates in Tables 1 and 2 are obtained from models that do not account for differences in child endowments and therefore may be biased. For example, mother's education is expected to be correlated with the child's intellectual endowment, and thus not controlling for the endowment will result in a biased estimate of the effect of mother's education on child cognitive achievement. A naive interpretation of the results in Table 3 may incorrectly conclude that more educated mothers are more productive in household production when in fact it is the unobserved child endowment that accounts for the relationship between mother's schooling and child cognitive achievement. In addition, the estimates in Tables 1 and 2 may be biased because the model includes variables that measure at most two years of inputs, when what is relevant is the entire history of inputs.

To address these issues, we re-estimated the basic models using a fixed effects methodology. This procedure examines the growth in child cognitive achievement and by taking first differences of the data eliminates the time invariant effect of the endowment on child cognitive achievement. Furthermore, the fixed effect methodology eliminates the need to have information about the cumulative amounts of inputs used to produce child cognitive achievement. The results from this analysis are listed in Tables 4, 5 and 6. Tables 4 and 5 list the estimates of all of the child health variables, and Table 6 lists a complete set of estimates from several representative models.

The set of explanatory variables differ somewhat from those used in the cross section. The county level variables and mother's age were dropped from the analysis. Very few 
families changed county in the two year period under analysis and the change in mother's age is perfectly correlated with the change in child's age. ${ }^{14}$ In addition, child age, the number of siblings and mother's education are measured in first differences between the two points in time when child cognitive achievement was assessed.

The estimates of the effect of child health on child cognitive achievement in Tables 4 and 5 differ significantly from those in Tables 1 and 2 . In particular, the estimates in Table 4 of the effect of height and weight on cognitive achievement are smaller and less significant for children age seven (five) and eight (six). These results imply that the anthropometric measures of child health are correlated with unobserved time invariant characteristics (e.g., intellectual endowment) that affect child cognitive development. Combined with the earlier cross sectional findings, these results are more evidence against the hypothesis that child health significantly affects child cognitive development. The direct measures of child health listed in Table 4, presence of medical condition, the number of illnesses, and presence of a serious illness, never obtain a .05 level of statistical significance. In fact, most of the estimates associated with these variables are either positive, or if negative, smaller than their standard error.

The estimates in Table 5 are even more counter intuitive. In Table 5 , the dependent variable is the change in the log scores on the PIAT math and reading recognition tests. The estimates of the effect of the child health variables from this model are in many cases positive and often statistically significant. In only one case, weight below 25 th percentile for 5 to 7 year olds, is the estimate negative and significant.

The fixed effects estimates of the effect of other variables in the model also differ from their cross sectional counterparts, as can be observed in Table 6. Although the estimates from all models are not listed, those that are listed are a fair representation of the

\footnotetext{
14 In addition to few changes in county, the county level variables are not updated in each survey year. For example, in the survey years 1988, 1990 and 1992, per capita income is measured as of 1988 . To check the sensitivity of the results, however, we also estimated models that included the changes in the county variables and the results were virtually unchanged from those reported in the text.
} 
full set of results. The most unexpected finding relates to mother's education, which is no longer significantly related to child cognitive development. This finding is the opposite of that found in almost all previous studies. One explanation of this result may be that most past studies failed to control for unobserved child specific characteristics. Two previous studies that have, Hanushek (1992) and Rosenzweig and Wolpin (1994), reach different conclusions. Hanushek (1992) reports that parental education has no effect on achievement, while Rosenzweig and Wolpin (1994) found that mother's education is significantly related to child cognitive achievement.

In their analysis, Rosenzweig and Wolpin (1994) found that maternal schooling has a positive effect on the child's PIAT reading and math test scores, but no effect on the child's score from the Peabody Picture Vocabulary Test (PPVT). The difference in the results between our study and that of Rosenzweig and Wolpin (1994) may be due to sample and methodological differences. For example, only about five percent of the mothers in our sample returned to school during the two year period under examination, whereas approximately 11 to 14 percent of the mothers in the Rosenzweig and Wolpin (1994) sample changed their level of education. ${ }^{15}$ To test the sensitivity of this result, we estimated a model using data on four year changes in cognitive achievement. For this sample, approximately 14 percent of the mothers returned to school. The estimates of the effect of mother's education on child cognitive achievement were positive and significant in only one case: for the sample of children who were age seven when first observed in a model that examined changes in the raw PIAT score. In all other models, mother's education was insignificantly different from zero, and in several cases negative.

In regard to other variables listed in Table 6, there are few statistically significant results. When the dependent variable is the raw PIAT score, child's age, race, and sex and

15 The five percent figure should represent an accurate measure of the number of women who increased their education. We eliminated any observations in which there was a change in the mother's education that was not associated with the mother reporting she had been enrolled in school, as well as any observations in which the education level decreased over time. 
mother's labor force participation tend to be significant, although the complete set of estimates are not robust. Black male children tend to have lower rates of growth in their test scores relative to white male children and female children tend to have higher rates of growth in their test scores than male children. These results are similar to those obtained in the cross sectional analysis, although much less robust. Mother's labor force participation remains a positive influence on cognitive achievement, particularly in models that examine changes in reading scores and is similar in magnitude to the cross sectional estimates.

For the models that use the change in log PIAT scores, few of the explanatory variables are significant. Child age is the only variable that exhibits a consistent pattern with regard the direction of the effect and the level of statistical significance. Achievement scores tend to increase faster the more months that elapse between assessments.

\section{Instrumental Variables Estimates}

The fixed effect methodology controls for unobserved time invariant effects and is a solution to the endogeneity problem caused by the omission of these factors from the regression model. As noted above, however, the possibility remains that some of the production inputs are endogenous in a structural way. To address this issue, we experimented with an instrumental variables (IV) procedure in which child health and mother's labor force participation were treated as endogenous in the fixed effect model. The variables used to create the instrumental variable for child health are all the variables listed

in Table 6 with the addition of: a dummy variable indicating that the child's birth weight was less than 2500 grams, a dummy variable indicating that the child stayed in the hospital longer than the mother at the time of birth, and a dummy variable indicating that the child was admitted to the hospital in the first year after birth. A similar set of instruments were used for mother's labor force participation, but instead of the health endowment measures used for child health, a variable measuring the woman's attitude toward work outside the home and the county level unemployment rate for the last two years were included as instruments.

The IV estimates did not yield plausible results, however, and thus we do not present 
the estimates in the paper. There were two basic problems with the IV estimator that prohibited obtaining precise estimates: multicollinearity and poor instruments. The multicollinearity problem was related to the mother's labor force participation variables. The variables chosen as instruments for mother's labor force participation performed relatively well. The first stage regressions had an adjusted R-Square of approximately .25 and the excluded instruments were usually significant at the .05 level. The predicted mother's labor force participation variables, however, were so highly correlated with each other and other variables (e.g., change in family size and AFDC participation) in the model that the estimates and standard errors of the parameters often increased by a factor of 20 to 50 as compared to the OLS estimates. We experimented with using only the proportion of weeks worked in the model, and in this case the estimates had approximately the same magnitude as the OLS estimates, but the standard errors were three or four times as large. In fact, we could not reject the hypothesis that mother's labor force participation was exogenous.

The problem of poor instruments pertains to the child health variables. Rarely were the excluded variables selected as instruments for child health significant in the first stage regressions. In fact, most of the F-Statistics associated with the first stage regression were not significant at the .05 level. This suggests that child health, as currently measured, is in all likelihood exogenous. This finding contrasts with the findings in Shakotko et al. (1981) which suggest that child intellectual development is a significant determinant of child health, although in that study the authors used cross sectional data and examined differences in the levels of child education and health.

\section{Conclusion}

In this paper we have extensively analyzed the impact of child health and other family characteristics on the cognitive achievement of children between the ages of five (seven) and seven (nine). We have improved upon past studies in a variety of ways and several of our results challenge the conclusions found in the existing literature. First, we find that child health as currently measured and child cognitive development are at best weakly related. 
This conclusion is based on estimates obtained using cross sectional and longitudinal data, and several measures of child health. These results are in opposition to the results reported in Edwards and Grossman (1979), Shakotko et al. (1981), Rosenzweig and Wolpin (1994), and Korenman et al. (1994), all of which found that child health had a significant impact on child cognitive achievement.

An important question is why our results differ from those of Rosenzweig and Wolpin (1994) and Korenman et al. (1994) who use the same data set and measures of child health and cognitive achievement. One major difference between our study and that of Rosenzweig and Wolpin (1994) is that the latter restrict their sample to families with at least two children, and use data only from the 1986 and 1988 NLSY surveys. These selection criteria result in a sample of women who became mothers relatively early in life, since the oldest NLSY respondent was 30 in 1988. In regard to Korenman et al. (1994), our cross sectional findings are consistent with their results, but our fixed effect estimates differ from their cross sectional results. These circumstances suggest that the cross sectional estimates may be biased due to an omitted variables problem. Anthropometric measures of child health may be correlated with the unobserved child endowment or with past levels of inputs which are omitted from cross sectional analyses.

Sample differences may also be the reason why our results differ from Edwards and Grossman (1979) and Shakotko et al. (1981). These authors examine the relationship between child health and cognitive achievement for a sample of children between the ages of 6 and 11 , and 12 and 16 respectively. They also use objective measures of child health whereas the measures currently used are primarily self reported. In addition to the above findings, preliminary tests strongly suggested that child health is not dependent on child cognitive achievement, as was suggested by Shakotko et al. (1981). Our tests appeared to indicate that our child health outcomes are predominantly random.

Our results also differ from the past literature with respect to variables measuring family inputs and characteristics. For example, we find that mother's schooling has little effect on child cognitive development after we control for differences in child intellectual 
endowments. This is a surprising finding since virtually all previous studies have found the opposite. We also find that mother's labor force participation tends to have positive impact on child cognitive development. Most previous studies have found no or a small negative effect of mother's labor force participation, particularly after the first year of birth. Our estimates indicate, however, that the cognitive development of children of women who work tends to be greater than that of women who do not work, although the findings were not uniform across specifications and age groups.

The differences in results between our study and past work, may be due to the fact that our study is one of a few to use a child specific fixed effects methodology to control for the effect of unobserved endowments. Most of the past studies are cross sectional and are therefore unable to completely control for differences in unobserved endowments. In a study that uses a similar methodology as the one currently employed, Hanushek (1992) reports several similar results to the ones we presented. For example, Hanushek (1992) states that parental education had no effect on achievement after a measure of permanent income was included in the model. He also reports that family structure had no effect on achievement. Contrary to what we find, however, Hanushek (1992) reports that mother's labor force participation had no effect on child cognitive achievement and that family income was positively related to achievement.

The results presented in this paper are important from a public policy perspective. Taken at face value, they suggest that one cost of poor child health is not diminished cognitive achievement. Therefore programs aimed at improving child health need to be justified without reference to the impact of child health on cognitive achievement. The results also suggest that child cognitive achievement is not very sensitive to changes in family structure, family income, or certain family characteristics such as mother's education. The results do identify one potentially important determinant of child cognitive achievement, however, and that is mother's labor force participation.

In summary, while our findings may appear counter-intuitive, there are several plausible explanations for our findings. First, children in poor health may forgo many types 
of play activities and as a result spend more time in cognitive enhancing activities. Second, although the model controlled for family resources at the aggregate level, including family size, a child in poor health may receive greater family contributions to offset there physical disadvantages. Third, many types of child health ailments are self limiting and of short duration and therefore may simply not affect cognitive development. Finally, the more serious illnesses which are of longer duration may be indistinguishable from other time invariant child specific effects controlled for by the fixed effect methodology. 


\section{References}

Baker, Paula and Frank Mott. 1992. "Following Children Over Time: Child Development and its Linkages with Family Social and Economic Transitions." Proceedings of Statistics Canada Symposium 92.

Becker, Gary S. "A Theory of the Allocation of Time." Economic Journal, Vol 75, 1965 : pp. 493-517.

Becker, Gary. A Treatise on the Family. Cambridge, Mass.: Harvard University Press, 1981: pp. 38-92.

Becker, Gary S. and H. Gregg Lewis. "On the Interaction between the Quantity and Quality of Children." Journal of Political Economy, Vol 81, No 2, March/April 1973: pp. S279-S289.

Blau, Francine D. and Adam J. Grossberg. "Maternal Labor Supply and Children's Cognitive Development." Review of Economics and Statistics, Vol. 74, No. 3, August 1992.

Broman, Sarah, Nichols, Paul and Wallace Kennedy. 1975. Preschool IQ: Prenatal and Early Developmental Correlates. Hillsdale, N.J.: Lawrence Erlbaum Associates.

Center for Human Resources. NLS Handbook, Columbus Ohio: Ohio State University Center for Human Resources, 1994.

Center for Human Resources. NLSY Child Handbook, Columbus Ohio: Ohio State University Center for Human Resources, 1993.

Congressional Budget Office. Educational Achievement: Explanations of Achievement Trends. Washington: U.S. Government Printing Office, 1987.

Datcher-Loury, Linda. "Family Background and School Achievement Among Low Income Blacks." The Journal of Human Resources, Vol 24, No 3, Summer 1989: pp. 528-544.

Desai, Sonalde, Lindsay Chase-Lansdale, and Robert Michael. "Mother or Market - Effects of Maternal Employment on the Intellectual Ability of 4 - Year - Old Children." Demography, Vol 26, November 1989: pp. S45-S62.

Edwards, Linda N. and Michael Grossman. "The Relationship Between Children's Health and Intellectual Development." In S. Mushkin, ed., Health: What is it Worth, Elmsford, N.Y.: Pergamon Press, 1979.

Fleischer, Belton M. "Mothers' Home Time and the Production of Child Quality." Demography, Vol 14, May 1977: pp. 197-212.

Frisancho, A. Roberto. 1990. Anthropometric Standards for the Assessment of Growth and 
Nutritional Status. Ann Arbor: The University of Michigan Press.

Hanushek, Eric A. "Conceptual and Empirical Issues in the Estimation of Educational Production Functions." Journal of Human Resources, Vol 14, No 3, Summer 1979: pp. 351-388.

Hanushek, Eric A. "The Economics of Schooling: Production and Efficiency in Public Schools." Journal of Economic Literature, Volume 24, No 3, September 1986: pp. 1141-1177.

Hanushek, Eric A. "The Trade-off Between Child Quantity and Quality." Journal of Political Economy, Vol 100, No 1, February 1992: pp. 84-117.

Hill, M. Anne and June O'Neill. "Family Endowments and the Achievement of Young Children with Special Reference to the Underclass." Journal of Human Resources (forthcoming)

Korenman, Sanders, Miller, Jane and John Sjaastad. 1994. "Long-Term Poverty and Child Development in the United States: Results from the NLSY." unpublished manuscript University of Minnesota.

Lazar, Irving and Richard Darlington. 1982. Lasting Effects of Early Education: A Report from the Consortium for Longitudinal Studies. Chicago: University of Chicago Press.

Leibowitz, Arleen. "Parental Inputs and Children's Achievement." Journal of Human Resources, Vol 12, Spring 1977: pp. 247-249.

Miller, Jane and Sanders Korenman. 1994. "Poverty and Children's Nutritional Status in the United States." American Journal of Epidemiology 140(3):233-43.

Olsen, Randall and Kenneth I. Wolpin. "The Impact of Exogenous Child Mortality on Fertility: A Waiting Time Regression with Dynamic Regressors. " Econometrica, Vol 51, 1983: pp. 731-749.

Ragosa, David R. and John B. Willett. "Understanding Correlates of Change by Modeling Individual Differencesin Growth." Psychometrica Vol. 50, No. 2, June 1985: pp.203228.

Rosenzweig, Mark R. "Birth Spacing and Sibling Inequality: Asymmetric Information within the Family." International Economic Review, Vol 27, No 1, February, 1986: pp. 55-76.

Rosenzweig, Mark R. and Kenneth I. Wolpin. "Heterogeneity, Intrafamily Distribution, and Child Health." The Journal of Human Resources, Vol 23, No 4, Fall 1988: pp. 437-461.

Rosenzweig, Mark R. and Kenneth I. Wolpin. "Are There Increasing Returns to the Intergenerational Production of Human Capital? Maternal Schooling and Child 
Intellectual Development, " Journal of Human Resources Vol. 29, No. 2, Spring 1994: pp. 670-693.

Rosenzweig, Mark and T. Paul Schultz. "Estimation a Household Production Function: Heterogeneity, The Demand for Health Inputs, and Their Effects on Birthweight." Journal of Political Economy, Vol 92, 1983: pp. 723-746.

Shakotko, Robert, Linda N. Edwards, and Michael Grossman. "An Exploration of the Dynamic Relationship Between Health and Cognitive Development in Adolescence." In J. van der Gaag and M. Perlman, eds., Health, Economics, and Health Economics, New York: North-Holland, 1981, 305-326. 
Table 1

Estimates of the Effects of Child Health on Child Cognitive Achievement

Cross-Sectional Regressions - Dependent Variable is PIAT Raw Score

(Standard Errors in Parentheses)

\begin{tabular}{|c|c|c|c|c|c|c|c|c|}
\hline \multirow[b]{2}{*}{ Variable } & \multicolumn{2}{|c|}{ Age 7} & \multicolumn{2}{|c|}{ Age 8} & \multicolumn{2}{|c|}{ Age 9} & \multicolumn{2}{|c|}{ Pooled Age Groups } \\
\hline & Reading & Math & Reading & Math & Reading & Math & Reading & Math \\
\hline Birth Weight & $\begin{array}{l}0.049 * * * \\
(0.014)\end{array}$ & $\begin{array}{l}0.049 * * * \\
(0.014)\end{array}$ & $\begin{array}{l}-0.011 \\
(0.017)\end{array}$ & $\begin{array}{c}0.003 \\
(0.015)\end{array}$ & $\begin{array}{c}0.015 \\
(0.021)\end{array}$ & $\begin{array}{c}0.023 \\
(0.017)\end{array}$ & $\begin{array}{c}0.018^{*} \\
(0.010)\end{array}$ & $\begin{array}{l}0.026 * * * \\
(0.009)\end{array}$ \\
\hline $\begin{array}{c}\text { Presence of } \\
\text { Medical Condition }\end{array}$ & $\begin{array}{l}-1.020 \\
(1.079)\end{array}$ & $\begin{array}{l}-2.696 * * * \\
(1.047)\end{array}$ & $\begin{array}{l}-1.151 \\
(1.283)\end{array}$ & $\begin{array}{l}-0.133 \\
(1.186)\end{array}$ & $\begin{array}{l}-0.699 \\
(1.392)\end{array}$ & $\begin{array}{l}-1.676 \\
(1.100)\end{array}$ & $\begin{array}{l}-0.899 \\
(0.715)\end{array}$ & $\begin{array}{l}-1.593 * * \\
(0.637)\end{array}$ \\
\hline $\begin{array}{l}\text { Number of } \\
\text { Illnesses }\end{array}$ & $\begin{array}{c}0.199 \\
(0.199)\end{array}$ & $\begin{array}{l}-0.014 \\
(0.192)\end{array}$ & $\begin{array}{c}0.214 \\
(0.211)\end{array}$ & $\begin{array}{c}0.147 \\
(0.196)\end{array}$ & $\begin{array}{l}-0.269 \\
(0.323)\end{array}$ & $\begin{array}{l}-0.169 \\
(0.262)\end{array}$ & $\begin{array}{c}0.088 \\
(0.135)\end{array}$ & $\begin{array}{c}0.036 \\
(0.121)\end{array}$ \\
\hline $\begin{array}{l}\text { Presence of Serious } \\
\text { Illness }\end{array}$ & $\begin{array}{l}-0.820 \\
(1.625)\end{array}$ & $\begin{array}{l}-4.027 * * * \\
(1.504)\end{array}$ & $\begin{array}{l}-2.834^{*} \\
(1.558)\end{array}$ & $\begin{array}{l}-0.547 \\
(1.437)\end{array}$ & $\begin{array}{l}-1.048 \\
(1.942)\end{array}$ & $\begin{array}{l}0.127 \\
(1.553)\end{array}$ & $\begin{array}{l}-1.560 \\
(0.969)\end{array}$ & $\begin{array}{l}-1.465^{*} \\
(0.854)\end{array}$ \\
\hline $\begin{array}{l}\text { Weight }<10 \text { th } \\
\text { Percentile }\end{array}$ & $\begin{array}{l}-4.124^{* * * *} \\
(1.121)\end{array}$ & $\begin{array}{l}-4.848 * * * \\
(1.068)\end{array}$ & $\begin{array}{l}-0.569 \\
(1.220)\end{array}$ & $\begin{array}{l}-1.875^{*} \\
(1.121)\end{array}$ & $\begin{array}{l}-1.594 \\
(1.515)\end{array}$ & $\begin{array}{l}-1.759 \\
(1.235)\end{array}$ & $\begin{array}{l}-1.948^{* * * *} \\
(0.728)\end{array}$ & $\begin{array}{l}-2.943 * * * \\
(0.648)\end{array}$ \\
\hline $\begin{array}{c}\text { Weight }<25 \text { th } \\
\text { Percentile }\end{array}$ & $\begin{array}{l}-1.794 * * \\
(0.715)\end{array}$ & $\begin{array}{l}-2.750^{* * *} \\
(0.686)\end{array}$ & $\begin{array}{c}1.082 \\
(0.936)\end{array}$ & $\begin{array}{l}-0.146 \\
(0.862)\end{array}$ & $\begin{array}{l}-0.931 \\
(1.133)\end{array}$ & $\begin{array}{l}-1.440 \\
(0.906)\end{array}$ & $\begin{array}{l}-0.578 \\
(0.522)\end{array}$ & $\begin{array}{l}-1.592^{* * *} \\
(0.463)\end{array}$ \\
\hline $\begin{array}{c}\text { Height }<10 \text { th } \\
\text { Percentile }\end{array}$ & $\begin{array}{l}-1.452^{*} \\
(0.860)\end{array}$ & $\begin{array}{l}-1.971 * * \\
(0.826)\end{array}$ & $\begin{array}{l}-0.351 \\
(1.204)\end{array}$ & $\begin{array}{l}-2.459 * * \\
(1.079)\end{array}$ & $\begin{array}{l}-1.352 \\
(1.354)\end{array}$ & $\begin{array}{l}-2.463^{* *} \\
(1.091)\end{array}$ & $\begin{array}{l}-0.999 * \\
(0.638)\end{array}$ & $\begin{array}{l}-2.372^{* * *} \\
(0.564)\end{array}$ \\
\hline $\begin{array}{l}\text { Height }<25 \text { th } \\
\text { Percentile }\end{array}$ & $\begin{array}{l}-1.798 * * \\
(0.696)\end{array}$ & $\begin{array}{l}-2.370^{* * *} \\
(0.671)\end{array}$ & $\begin{array}{l}-1.231 \\
(0.905)\end{array}$ & $\begin{array}{l}-2.670^{* * *} \\
(0.821)\end{array}$ & $\begin{array}{l}-1.663 \\
(1.075)\end{array}$ & $\begin{array}{l}-1.823^{*} \\
(0.872)\end{array}$ & $\begin{array}{l}-1.533^{* * *} \\
(0.502)\end{array}$ & $\begin{array}{l}-2.443 * * * \\
(0.446)\end{array}$ \\
\hline $\begin{array}{l}\text { Body Mass Index } \\
<10 \text { th Percentile }\end{array}$ & $\begin{array}{l}-0.898 \\
(0.769)\end{array}$ & $\begin{array}{l}-1.790^{* *} \\
(0.747)\end{array}$ & $\begin{array}{c}0.165 \\
(0.948)\end{array}$ & $\begin{array}{l}-0.728 \\
(0.885)\end{array}$ & $\begin{array}{l}-0.398 \\
(1.316)\end{array}$ & $\begin{array}{l}-0.952 \\
(1.075)\end{array}$ & $\begin{array}{l}-0.325 \\
(0.559)\end{array}$ & $\begin{array}{l}-1.232^{* *} \\
(0.505)\end{array}$ \\
\hline $\begin{array}{l}\text { Body Mass Index } \\
<25 \text { th Percentile }\end{array}$ & $\begin{array}{l}-0.932 \\
(0.655)\end{array}$ & $\begin{array}{l}-2.556^{* * *} \\
(0.631)\end{array}$ & $\begin{array}{c}0.790 \\
(0.801)\end{array}$ & $\begin{array}{c}0.470 \\
(0.747)\end{array}$ & $\begin{array}{l}-0.033 \\
(1.012)\end{array}$ & $\begin{array}{l}-0.673 \\
(0.819)\end{array}$ & $\begin{array}{l}-0.085 \\
(0.463)\end{array}$ & $\begin{array}{l}-0.986 * * \\
(0.417)\end{array}$ \\
\hline Obs. & 848 & 869 & 776 & 794 & 682 & 686 & 2306 & 2349 \\
\hline
\end{tabular}

Notes: The dependent variables are the raw score on the PIAT math and reading recognition tests. Each cell lists an estimate of the effect of child health obtained from a separate regression model for each variable. All models include the following variables: child's age, race and sex; mother's age, education, marital status, and labor force participation; family size, income and poverty status; county crime rate, per capita income and percentage of households headed by females; and year dummy variables. See the appendix for a complete list of the variables. 
Table 2

Estimates of the Effects of Child Health on Child Cognitive Achievement

Cross-Sectional Regressions- Dependent Variable is Natural Logarithm of PIAT Score (Standard Errors in Parentheses)

\begin{tabular}{|c|c|c|c|c|c|c|c|c|}
\hline \multirow[b]{2}{*}{ Variable } & \multicolumn{2}{|c|}{ Age 7} & \multicolumn{2}{|c|}{ Age 8} & \multicolumn{2}{|c|}{ Age 9} & \multicolumn{2}{|c|}{ Pooled Age Groups } \\
\hline & Reading & Math & Reading & Math & Reading & Math & Reading & Math \\
\hline Birth Weight & $\begin{array}{l}0.002^{* * *} \\
(0.000)\end{array}$ & $\begin{array}{l}0.002^{* * *} \\
(0.001)\end{array}$ & $\begin{array}{l}-0.000 \\
(0.000)\end{array}$ & $\begin{array}{l}-0.000 \\
(0.001)\end{array}$ & $\begin{array}{c}0.000 \\
(0.001)\end{array}$ & $\begin{array}{c}0.001 \\
(0.000)\end{array}$ & $\begin{array}{l}0.001 * * \\
(0.000)\end{array}$ & $\begin{array}{l}0.001 * * * \\
(0.000)\end{array}$ \\
\hline $\begin{array}{l}\text { Presence of } \\
\text { Medical } \\
\text { Condition }\end{array}$ & $\begin{array}{l}-0.034 \\
(0.036)\end{array}$ & $\begin{array}{l}-0.114 * * * \\
(0.041)\end{array}$ & $\begin{array}{l}-0.032 \\
(0.036)\end{array}$ & $\begin{array}{l}-0.018 \\
(0.040)\end{array}$ & $\begin{array}{l}-0.026 \\
(0.035)\end{array}$ & $\begin{array}{l}-0.052 \\
(0.031)\end{array}$ & $\begin{array}{l}-0.028 \\
(0.020)\end{array}$ & $\begin{array}{l}-0.063^{* * *} \\
(0.022)\end{array}$ \\
\hline $\begin{array}{l}\text { Number of } \\
\text { Illnesses }\end{array}$ & $\begin{array}{c}0.006 \\
(0.007)\end{array}$ & $\begin{array}{l}-0.001 \\
(0.007)\end{array}$ & $\begin{array}{c}0.006 \\
(0.006)\end{array}$ & $\begin{array}{c}0.005 \\
(0.007)\end{array}$ & $\begin{array}{l}-0.007 \\
(0.008)\end{array}$ & $\begin{array}{l}-0.006 \\
(0.008)\end{array}$ & $\begin{array}{c}0.003 \\
(0.004)\end{array}$ & $\begin{array}{c}0.001 \\
(0.004)\end{array}$ \\
\hline $\begin{array}{l}\text { Presence of } \\
\text { Serious Illness }\end{array}$ & $\begin{array}{l}-0.014 \\
(0.054)\end{array}$ & $\begin{array}{l}-0.161 * * * \\
(0.059)\end{array}$ & $\begin{array}{l}-0.076^{*} \\
(0.044)\end{array}$ & $\begin{array}{l}-0.027 \\
(0.048)\end{array}$ & $\begin{array}{l}-0.032 \\
(0.048)\end{array}$ & $\begin{array}{c}0.000 \\
(0.044)\end{array}$ & $\begin{array}{l}-0.040 \\
(0.028)\end{array}$ & $\begin{array}{l}-0.057^{*} \\
(0.029)\end{array}$ \\
\hline $\begin{array}{c}\text { Weight }<10 \text { th } \\
\text { Percentile }\end{array}$ & $\begin{array}{l}-0.161^{* * *} \\
(0.037)\end{array}$ & $\begin{array}{l}-0.206^{* * *} \\
(0.042)\end{array}$ & $\begin{array}{l}-0.015 \\
(0.034)\end{array}$ & $\begin{array}{l}-0.056 \\
(0.038)\end{array}$ & $\begin{array}{l}-0.047 \\
(0.038)\end{array}$ & $\begin{array}{l}-0.055 \\
(0.035)\end{array}$ & $\begin{array}{l}-0.069^{* * *} \\
(0.021)\end{array}$ & $\begin{array}{l}-0.110^{* * *} \\
(0.022)\end{array}$ \\
\hline $\begin{array}{c}\text { Weight }<25 \text { th } \\
\text { Percentile }\end{array}$ & $\begin{array}{l}-0.072^{* * *} \\
(0.024)\end{array}$ & $\begin{array}{l}-0.111^{* * *} \\
(0.027)\end{array}$ & $\begin{array}{c}0.031 \\
(0.026)\end{array}$ & $\begin{array}{c}0.002 \\
(0.029)\end{array}$ & $\begin{array}{l}-0.038 \\
(0.028)\end{array}$ & $\begin{array}{l}-0.043^{*} \\
(0.026)\end{array}$ & $\begin{array}{l}-0.028^{*} \\
(0.015)\end{array}$ & $\begin{array}{l}-0.058 * * * \\
(0.016)\end{array}$ \\
\hline $\begin{array}{l}\text { Height }<10 \text { th } \\
\text { Percentile }\end{array}$ & $\begin{array}{l}-0.057^{* *} \\
(0.028)\end{array}$ & $\begin{array}{l}-0.090 * * * \\
(0.032)\end{array}$ & $\begin{array}{l}-0.017 \\
(0.034)\end{array}$ & $\begin{array}{l}-0.089^{* *} \\
(0.036)\end{array}$ & $\begin{array}{l}-0.033 \\
(0.034)\end{array}$ & $\begin{array}{l}-0.070^{* *} \\
(0.031)\end{array}$ & $\begin{array}{l}-0.035^{*} \\
(0.018)\end{array}$ & $\begin{array}{l}-0.089 * * * \\
(0.019)\end{array}$ \\
\hline $\begin{array}{c}\text { Height }<25 \text { th } \\
\text { Percentile }\end{array}$ & $\begin{array}{l}-0.065^{* *} \\
(0.023)\end{array}$ & $\begin{array}{l}-0.098^{* * *} \\
(0.026)\end{array}$ & $\begin{array}{l}-0.040 \\
(0.025)\end{array}$ & $\begin{array}{l}-0.092^{* * *} \\
(0.027)\end{array}$ & $\begin{array}{l}-0.050^{*} \\
(0.027)\end{array}$ & $\begin{array}{l}-0.051 * * \\
(0.025)\end{array}$ & $\begin{array}{l}-0.052 * * * \\
(0.014)\end{array}$ & $\begin{array}{l}-0.088^{* * * *} \\
(0.015)\end{array}$ \\
\hline $\begin{array}{c}\text { Body Mass } \\
\text { Index }<10^{\text {th }} \\
\text { Percentile }\end{array}$ & $\begin{array}{l}-0.034 \\
(0.025)\end{array}$ & $\begin{array}{l}-0.069^{* *} \\
(0.029)\end{array}$ & $\begin{array}{c}0.006 \\
(0.027)\end{array}$ & $\begin{array}{l}-0.020 \\
(0.030)\end{array}$ & $\begin{array}{l}-0.018 \\
(0.033)\end{array}$ & $\begin{array}{l}-0.031 \\
(0.031)\end{array}$ & $\begin{array}{l}-0.013 \\
(0.016)\end{array}$ & $\begin{array}{l}-0.043^{* *} \\
(0.017)\end{array}$ \\
\hline $\begin{array}{c}\text { Body Mass } \\
\text { Index }<25 \text { th } \\
\text { Percentile }\end{array}$ & $\begin{array}{l}-0.038 \\
(0.022)\end{array}$ & $\begin{array}{l}-0.095^{* * *} \\
(0.025)\end{array}$ & $\begin{array}{c}0.028 \\
(0.023)\end{array}$ & $\begin{array}{c}0.022 \\
(0.025)\end{array}$ & $\begin{array}{l}-0.012 \\
(0.025)\end{array}$ & $\begin{array}{l}-0.015 \\
(0.023)\end{array}$ & $\begin{array}{l}-0.008 \\
(0.013)\end{array}$ & $\begin{array}{l}-0.033^{* *} \\
(0.014)\end{array}$ \\
\hline Obs. & 848 & 869 & 776 & 794 & 682 & 686 & 2306 & 2349 \\
\hline
\end{tabular}

Notes: The dependent variables are the natural logartthm of the score on the PIAT math and reading recognition tests. Each cell lists an estimate of the effect of child health obtained from a separate regression model for each variable. All models include the following variables: child's age, race and sex; mother's age, education, marital status, and labor force participation; family size, income and poverty status; county crime rate, per capita income and percentage of households headed by females; and year dummy variables. See the appendix for a complete list of the variables.

*** Significant at $1 \%$ level, **5\% level, *10\% level 
Table 3

Sample Regression Results--Cross-Sectional Regressions

Dependent Variable: PIAT Reading Recognition Score

\begin{tabular}{|c|c|c|c|c|c|c|c|c|}
\hline \multirow[b]{2}{*}{ Variable } & \multicolumn{2}{|c|}{ Age 7- Raw PIAT Score } & \multicolumn{2}{|c|}{ Age 7- Log PIAT Score } & \multicolumn{2}{|c|}{ Age 9-Raw PIAT Score } & \multicolumn{2}{|c|}{ Age 9 - Log PIAT Score } \\
\hline & Coeff & s.e. & Coeff & s.e. & Coeff & s.e. & Coeff & s.e. \\
\hline Intercept & $-39.605^{* * *}$ & 7.996 & $1.090 * * *$ & 0.264 & $41.226^{* *}$ & 13.988 & $1.656^{* * *}$ & 0.348 \\
\hline BLACK & -0.697 & 0.959 & -0.019 & 0.032 & $-3.051^{* *}$ & 1.421 & $-0.089 * *$ & 0.035 \\
\hline FEMALE & 1.528 & 0.727 & $0.052 * *$ & 0.024 & $2.546 * *$ & 1.099 & $0.062^{* * *}$ & 0.027 \\
\hline $\begin{array}{l}\text { FEMALE } x \\
\text { BLACK }\end{array}$ & -0.869 & 1.140 & -0.016 & 0.038 & -0.794 & 1.635 & -0.009 & 0.041 \\
\hline CHILD AGE & $0.610^{* * *}$ & 0.074 & $0.020^{* * *}$ & 0.002 & $0.558 * * *$ & 0.107 & $0.014 * * *$ & 0.003 \\
\hline NUMSIBS & $-0.959 * *$ & 0.295 & $-0.032 * * *$ & 0.010 & -0.606 & 0.392 & $-0.016^{*}$ & 0.010 \\
\hline $\begin{array}{l}\text { FAMILY } \\
\text { INCOME }\end{array}$ & $0.023^{*}$ & 0.014 & 0.001 & 0.000 & -0.003 & 0.019 & -0.000 & 0.000 \\
\hline $\begin{array}{l}\text { MISSING } \\
\text { INCOME }\end{array}$ & 0.124 & 0.124 & 0.007 & 0.037 & -2.044 & 1.563 & -0.062 & 0.039 \\
\hline PCTMAR & 0.576 & 0.972 & 0.034 & 0.032 & 2.328 & 1.438 & 0.050 & 0.036 \\
\hline PCTDIV & 0.195 & 0.955 & 0.018 & 0.032 & 0.025 & 1.360 & 0.003 & 0.034 \\
\hline MLFP & $3.765 * *$ & 1.745 & $0.132^{* *}$ & 0.058 & $5.505^{* *}$ & 2.504 & $0.129 * *$ & 0.062 \\
\hline MHRS & -0.019 & 0.028 & -0.001 & 0.001 & -0.013 & 0.041 & 0.000 & 0.001 \\
\hline MLFP $\times$ MHRS & -0.079 & 0.051 & -0.003 & 0.002 & $-0.123 *$ & 0.072 & $-0.003 *$ & 0.002 \\
\hline PCTAFDC & $-2.809^{* *}$ & 1.097 & $-0.101^{* * *}$ & 0.036 & -2.469 & 1.570 & $-0.078^{* *}$ & 0.039 \\
\hline $\begin{array}{l}\text { MOTHER'S } \\
\text { EDUCATION }\end{array}$ & $0.794 * * *$ & 0.159 & $0.026^{* * *}$ & 0.005 & $1.416^{* * *}$ & 0.250 & $0.035^{* * *}$ & 0.006 \\
\hline MOTHER'S AGE & 0.083 & 0.138 & 0.001 & 0.005 & -0.071 & 0.210 & -0.002 & 0,005 \\
\hline CRIME & -0.081 & 0.144 & -0.005 & 0.005 & -0.107 & 0.202 & -0.004 & 0.005 \\
\hline PCAPINC & $0.513^{* * *}$ & 0.163 & $0.018^{* * *}$ & 0.005 & $0.515 * *$ & 0.227 & $0.014 * *$ & 0.006 \\
\hline PCTFHEAD & -0.050 & 0.069 & -0.001 & 0.002 & 0.082 & 0.098 & 0.003 & 0.002 \\
\hline $\begin{array}{l}\text { PRESENCE OF } \\
\text { MEDICAL } \\
\text { CONDITION }\end{array}$ & -1.020 & 1.079 & -0.034 & 0.036 & -0.699 & 1.392 & -0.026 & 0.035 \\
\hline YEAR90 & 0.708 & 0.822 & -0.024 & 0.027 & 1.720 & 1.199 & 0.036 & 0.030 \\
\hline YEAR92 & 0.259 & 0.975 & 0.019 & 0.032 & 0.195 & 1.345 & 0.001 & 0.033 \\
\hline Adj. $R^{2}$ & 0.212 & & 0.215 & & 0.180 & & 0.188 & \\
\hline Observations & 848 & & 848 & & 682 & & 682 & \\
\hline
\end{tabular}

*** Significant at $1 \%$ level, **5\% level, *10\% level. 
Table 4

Estimates of the Effects of Child Health on Child Cognitive Development

Fixed Effect Regressions - Dependent Variable is PIAT Raw Score

(Standard Errors in Parentheses)

\begin{tabular}{|c|c|c|c|c|c|c|c|c|}
\hline \multirow[b]{2}{*}{ Variable } & \multicolumn{2}{|c|}{ Age 5 to 7} & \multicolumn{2}{|c|}{ Age 6 to 8} & \multicolumn{2}{|c|}{ Age 7 to 9} & \multicolumn{2}{|c|}{ Pooled Age Groups } \\
\hline & Reading & Math & Reading & Math & Reading & Math & Reading & Math \\
\hline Birth Weight & $\begin{array}{c}0.025^{*} \\
(0.013)\end{array}$ & $\begin{array}{l}0.043^{* * *} \\
(0.014)\end{array}$ & $\begin{array}{l}-0.012 \\
(0.015)\end{array}$ & $\begin{array}{c}0.008 \\
(0.014)\end{array}$ & $\begin{array}{l}-0.021 \\
(0.016)\end{array}$ & $\begin{array}{l}-0.015 \\
(0.016)\end{array}$ & $\begin{array}{l}-0.003 \\
(0.008)\end{array}$ & $\begin{array}{c}0.014^{*} \\
(0.008)\end{array}$ \\
\hline $\begin{array}{l}\text { Presence of } \\
\text { Medical } \\
\text { Condition }\end{array}$ & $\begin{array}{c}0.377 \\
(0.500)\end{array}$ & $\begin{array}{l}-0.709 \\
(0.520)\end{array}$ & $\begin{array}{l}-0.440 \\
(0.569)\end{array}$ & $\begin{array}{c}0.100 \\
(0.540)\end{array}$ & $\begin{array}{c}0.678 \\
(0.569)\end{array}$ & $\begin{array}{c}0.491 \\
(0.545)\end{array}$ & $\begin{array}{c}0.490 \\
(0.626)\end{array}$ & $\begin{array}{l}-0.100 \\
(0.615)\end{array}$ \\
\hline $\begin{array}{l}\text { Number of } \\
\text { Illnesses }\end{array}$ & $\begin{array}{c}0.396 \\
(0.176)\end{array}$ & $\begin{array}{c}0.105 \\
(0.182)\end{array}$ & $\begin{array}{c}0.296 \\
(0.212)\end{array}$ & $\begin{array}{c}0.130 \\
(0.203)\end{array}$ & $\begin{array}{l}-0.000 \\
(0.272)\end{array}$ & $\begin{array}{c}0.009 \\
(0.267)\end{array}$ & $\begin{array}{c}0.267 \\
(0.122)\end{array}$ & $\begin{array}{c}0.107 \\
(0.121)\end{array}$ \\
\hline $\begin{array}{c}\text { Presence of } \\
\text { Serious Illness }\end{array}$ & $\begin{array}{c}1.934 \\
(1.504)\end{array}$ & $\begin{array}{l}-2.589 * \\
(1.488)\end{array}$ & $\begin{array}{l}-2.027 \\
(1.405)\end{array}$ & $\begin{array}{l}-0.881 \\
(1.329)\end{array}$ & $\begin{array}{l}-0.075 \\
(1.652)\end{array}$ & $\begin{array}{c}0.731 \\
(1.631)\end{array}$ & $\begin{array}{l}-0.028 \\
(0.863)\end{array}$ & $\begin{array}{l}-0.959 \\
(0.843)\end{array}$ \\
\hline $\begin{array}{c}\text { Weight }< \\
10 \text { th } \\
\text { Percentile }\end{array}$ & $\begin{array}{l}-2.374^{* *} \\
(1.038)\end{array}$ & $\begin{array}{l}-3.611^{* * *} \\
(1.076)\end{array}$ & $\begin{array}{l}-0.515 \\
(1.078)\end{array}$ & $\begin{array}{l}-1.180 \\
(1.025)\end{array}$ & $\begin{array}{l}-0.698 \\
(1.179)\end{array}$ & $\begin{array}{c}1.443 \\
(1.174)\end{array}$ & $\begin{array}{l}-1.190^{*} \\
(0.626)\end{array}$ & $\begin{array}{l}-1.323 * * \\
(0.622)\end{array}$ \\
\hline $\begin{array}{l}\text { Weight }< \\
\text { 25th } \\
\text { Percentile }\end{array}$ & $\begin{array}{l}-1.051 \\
(0.658)\end{array}$ & $\begin{array}{l}-2.720 * * * \\
(0.677)\end{array}$ & $\begin{array}{c}0.820 \\
(0.818)\end{array}$ & $\begin{array}{c}0.244 \\
(0.776)\end{array}$ & $\begin{array}{c}0.630 \\
(0.872)\end{array}$ & $\begin{array}{l}1.430^{*} \\
(0.853)\end{array}$ & $\begin{array}{c}0.038 \\
(0.445)\end{array}$ & $\begin{array}{l}-0.643 \\
(0.439)\end{array}$ \\
\hline $\begin{array}{c}\text { Height }< \\
10 \text { th } \\
\text { Percentile }\end{array}$ & $\begin{array}{l}-1.720^{* *} \\
(0.781)\end{array}$ & $\begin{array}{l}-1.820^{* *} \\
(0.807)\end{array}$ & $\begin{array}{l}-0.406 \\
(1.070)\end{array}$ & $\begin{array}{l}-2.100^{* *} \\
(0.992)\end{array}$ & $\begin{array}{c}0.299 \\
(1.022)\end{array}$ & $\begin{array}{c}0.600 \\
(1.004)\end{array}$ & $\begin{array}{l}-0.665 \\
(0.540)\end{array}$ & $\begin{array}{l}-1.192^{* *} \\
(0.530)\end{array}$ \\
\hline $\begin{array}{c}\text { Height }< \\
\text { 25th } \\
\text { Percentile }\end{array}$ & $\begin{array}{l}-1.722 * * \\
(0.631)\end{array}$ & $\begin{array}{l}-2.167^{* * *} \\
(0.654)\end{array}$ & $\begin{array}{l}-0.639 \\
(0.806)\end{array}$ & $\begin{array}{l}-1.467^{*} \\
(0.755)\end{array}$ & $\begin{array}{c}0.019 \\
(0.821)\end{array}$ & $\begin{array}{c}1.160 \\
(0.811)\end{array}$ & $\begin{array}{l}-0.809^{*} \\
(0.427)\end{array}$ & $\begin{array}{l}-1.004^{* *} \\
(0.422)\end{array}$ \\
\hline $\begin{array}{c}\text { Body Mass } \\
\text { Index }<10 \text { th } \\
\text { Percentile }\end{array}$ & $\begin{array}{c}0.021 \\
(0.707)\end{array}$ & $\begin{array}{l}-1.344^{*} \\
(0.739)\end{array}$ & $\begin{array}{l}-0.485 \\
(0.828)\end{array}$ & $\begin{array}{l}-1.020 \\
(0.794)\end{array}$ & $\begin{array}{l}-0.052 \\
(1.026)\end{array}$ & $\begin{array}{c}1.171 \\
(1.027)\end{array}$ & $\begin{array}{l}-0.131 \\
(0.478)\end{array}$ & $\begin{array}{l}-0.683 \\
(0.478)\end{array}$ \\
\hline $\begin{array}{l}\text { Body Mass } \\
\text { Index }<25 \text { th } \\
\text { Percentile }\end{array}$ & $\begin{array}{l}-0.017 \\
(0.595)\end{array}$ & $\begin{array}{l}-2.085^{* * *} \\
(0.618)\end{array}$ & $\begin{array}{c}0.034 \\
(0.703)\end{array}$ & $\begin{array}{l}-0.218 \\
(0.674)\end{array}$ & $\begin{array}{c}0.185 \\
(0.783)\end{array}$ & $\begin{array}{c}0.783 \\
(0.774)\end{array}$ & $\begin{array}{c}0.113 \\
(0.393)\end{array}$ & $\begin{array}{c}-0.664^{*} \\
(0.392)\end{array}$ \\
\hline Obs. & 812 & 830 & 744 & 760 & 651 & 655 & 2207 & 2245 \\
\hline
\end{tabular}

Notes: The dependent variables are the change in the raw score of the PIAT math and reading recognition tests. Each cell lists an estimate of the effect of child health obtained from a separate regression model. All models include the following variables: child's age, race and sex; mother's age, education, marital status, and labor force participation; family size, income and poverty status; county crime rate, per capita income and percentage of households headed by females; and year dummy variables. See the appendix for a complete list of the variables.

*** Significant at $1 \%$ level, $* * 5 \%$ level, ${ }^{*} 10 \%$ level 
Table 5

Estimates of the Effects of Child Health on Child Cognitive Development

Fixed Effect Regressions - Dependent Variable is Natural Logarithm of PIAT Score (Standard Errors in Parentheses)

\begin{tabular}{|c|c|c|c|c|c|c|c|c|}
\hline \multirow[b]{2}{*}{ Variable } & \multicolumn{2}{|c|}{ Age 5 to 7} & \multicolumn{2}{|c|}{ Age 6 to 8} & \multicolumn{2}{|c|}{ Age 7 to 9} & \multicolumn{2}{|c|}{ Pooled Age Groups } \\
\hline & Reading & Math & Reading & Math & Reading & Math & Reading & Math \\
\hline Birth Weight & $\begin{array}{l}-0.001 * * \\
(0.001)\end{array}$ & $\begin{array}{c}0.001 * \\
(0.001)\end{array}$ & $\begin{array}{l}-0.000 \\
(0.000)\end{array}$ & $\begin{array}{c}0.001 \\
(0.001)\end{array}$ & $\begin{array}{l}-0.001 * * \\
(0.000)\end{array}$ & $\begin{array}{l}-0.001 \\
(0.001)\end{array}$ & $\begin{array}{l}-0.001 * * * \\
(0.000)\end{array}$ & $\begin{array}{c}0.000 \\
(0.000)\end{array}$ \\
\hline $\begin{array}{l}\text { Presence of } \\
\text { Medical } \\
\text { Condition }\end{array}$ & $\begin{array}{c}0.041^{*} \\
(0.023)\end{array}$ & $\begin{array}{l}-0.017 \\
(0.024)\end{array}$ & $\begin{array}{l}-0.014 \\
(0.019)\end{array}$ & $\begin{array}{c}0.007 \\
(0.022)\end{array}$ & $\begin{array}{c}0.026^{*} \\
(0.015)\end{array}$ & $\begin{array}{l}0.045^{* *} \\
(0.019)\end{array}$ & $\begin{array}{c}0.038 \\
(0.023)\end{array}$ & $\begin{array}{c}0.019 \\
(0.025)\end{array}$ \\
\hline $\begin{array}{l}\text { Number of } \\
\text { Illnesses }\end{array}$ & $\begin{array}{l}0.019 * * \\
(0.008)\end{array}$ & $\begin{array}{c}0.007 \\
(0.008)\end{array}$ & $\begin{array}{c}0.003 \\
(0.007)\end{array}$ & $\begin{array}{c}0.002 \\
(0.008)\end{array}$ & $\begin{array}{l}-0.000 \\
(0.007)\end{array}$ & $\begin{array}{c}0.001 \\
(0.009)\end{array}$ & $\begin{array}{l}0.009^{* *} \\
(0.004)\end{array}$ & $\begin{array}{c}0.004 \\
(0.005)\end{array}$ \\
\hline $\begin{array}{l}\text { Presence of } \\
\text { Serious } \\
\text { Illness }\end{array}$ & $\begin{array}{l}0.189 * * * \\
(0.069)\end{array}$ & $\begin{array}{l}-0.075 \\
(0.069)\end{array}$ & $\begin{array}{l}-0.026 \\
(0.046)\end{array}$ & $\begin{array}{l}-0.035 \\
(0.0541)\end{array}$ & $\begin{array}{l}-0.014 \\
(0.044)\end{array}$ & $\begin{array}{c}0.036 \\
(0.057)\end{array}$ & $\begin{array}{c}0.049 \\
(0.031)\end{array}$ & $\begin{array}{l}-0.031 \\
(0.035)\end{array}$ \\
\hline $\begin{array}{c}\text { Weight }< \\
10 \text { th } \\
\text { Percentile }\end{array}$ & $\begin{array}{c}0.055 \\
(0.048)\end{array}$ & $\begin{array}{l}-0.056 \\
(0.050)\end{array}$ & $\begin{array}{l}-0.026 \\
(0.035)\end{array}$ & $\begin{array}{l}-0.019 \\
(0.042)\end{array}$ & $\begin{array}{c}0.002 \\
(0.031)\end{array}$ & $\begin{array}{l}0.107^{* * *} \\
(0.041)\end{array}$ & $\begin{array}{c}0.002 \\
(0.023)\end{array}$ & $\begin{array}{c}0.003 \\
(0.026)\end{array}$ \\
\hline $\begin{array}{l}\text { Weight }< \\
25 \text { th } \\
\text { Percentile }\end{array}$ & $\begin{array}{c}0.027 \\
(0.030)\end{array}$ & $\begin{array}{l}-0.069 * * \\
(0.032)\end{array}$ & $\begin{array}{c}0.011 \\
(0.027)\end{array}$ & $\begin{array}{c}0.020 \\
(0.032)\end{array}$ & $\begin{array}{c}0.035 \\
(0.023)\end{array}$ & $\begin{array}{l}0.088^{* * *} \\
(0.030)\end{array}$ & $\begin{array}{c}0.023 \\
(0.016)\end{array}$ & $\begin{array}{c}0.002 \\
(0.018)\end{array}$ \\
\hline $\begin{array}{c}\text { Height }< \\
10 \text { th } \\
\text { Percentile }\end{array}$ & $\begin{array}{l}-0.038 \\
(0.036)\end{array}$ & $\begin{array}{l}-0.027 \\
(0.038)\end{array}$ & $\begin{array}{c}0.007 \\
(0.035)\end{array}$ & $\begin{array}{l}-0.058 \\
(0.040)\end{array}$ & $\begin{array}{c}0.041 \\
(0.027)\end{array}$ & $\begin{array}{l}0.078 * * \\
(0.035)\end{array}$ & $\begin{array}{l}-0.004 \\
(0.019)\end{array}$ & $\begin{array}{l}-0.007 \\
(0.022)\end{array}$ \\
\hline $\begin{array}{l}\text { Height }< \\
\text { 25th } \\
\text { Percentile }\end{array}$ & $\begin{array}{l}-0.031 \\
(0.029)\end{array}$ & $\begin{array}{l}-0.042 \\
(0.030)\end{array}$ & $\begin{array}{l}-0.010 \\
(0.026)\end{array}$ & $\begin{array}{l}-0.036 \\
(0.031)\end{array}$ & $\begin{array}{c}0.027 \\
(0.022)\end{array}$ & $\begin{array}{l}0.091 * * * \\
(0.028)\end{array}$ & $\begin{array}{l}-0.008 \\
(0.015)\end{array}$ & $\begin{array}{l}-0.004 \\
(0.017)\end{array}$ \\
\hline $\begin{array}{l}\text { Body Mass } \\
\text { Index }<10 \text { th } \\
\text { Percentile }\end{array}$ & $\begin{array}{c}0.061^{*} \\
(0.032)\end{array}$ & $\begin{array}{l}-0.009 \\
(0.034)\end{array}$ & $\begin{array}{l}-0.032 \\
(0.027)\end{array}$ & $\begin{array}{l}-0.036 \\
(0.032)\end{array}$ & $\begin{array}{c}0.010 \\
(0.027)\end{array}$ & $\begin{array}{c}0.063 * \\
(0.036)\end{array}$ & $\begin{array}{c}0.014 \\
(0.017)\end{array}$ & $\begin{array}{l}-0.003 \\
(0.020)\end{array}$ \\
\hline $\begin{array}{c}\text { Body Mass } \\
\text { Index }<25 \text { th } \\
\text { Percentile }\end{array}$ & $\begin{array}{l}0.059^{* *} \\
(0.027)\end{array}$ & $\begin{array}{l}-0.030 \\
(0.029)\end{array}$ & $\begin{array}{l}-0.019 \\
(0.023)\end{array}$ & $\begin{array}{l}-0.017 \\
(0.027)\end{array}$ & $\begin{array}{c}0.007 \\
(0.021)\end{array}$ & $\begin{array}{c}0.044^{*} \\
(0.027)\end{array}$ & $\begin{array}{c}0.019 \\
(0.014)\end{array}$ & $\begin{array}{l}-0.004 \\
(0.016)\end{array}$ \\
\hline Obs. & 812 & 830 & 744 & 760 & 651 & 655 & 2207 & 2245 \\
\hline
\end{tabular}

Notes: The dependent variables are the change in the natural logarithm of score of the PIAT math and reading recognition tests. Each cell lists an estimate of the effect of child health obtained from a separate regression model. All models include the following variables: child's age, race and sex; mother's age, education, marital status, and labor force participation; family size, income and poverty status; county cnme rate, per capita income and percentage of households headed by females; and year dummy vanables. See the appendix for a complete list of the vanables.

*** Significant at $1 \%$ level, ${ }^{* * 5 \%}$ level, ${ }^{*} 10 \%$ level 
Table 6

Sample Regression Results-Cross-Sectional Regressions

Dependent Variable: Change in PIAT Reading Recognition Score

\begin{tabular}{|c|c|c|c|c|c|c|c|c|}
\hline \multirow[b]{2}{*}{ Variable } & \multicolumn{2}{|c|}{$\begin{array}{c}\text { Age } 5 \text { to } 7 \text { - Raw PIAT } \\
\text { Score }\end{array}$} & \multicolumn{2}{|c|}{$\begin{array}{c}\text { Age } 5 \text { to } 7 \text { - Log PIAT } \\
\text { Score }\end{array}$} & \multicolumn{2}{|c|}{$\begin{array}{c}\text { Age } 7 \text { to } 9 \text { - Raw PIAT } \\
\text { Score }\end{array}$} & \multicolumn{2}{|c|}{$\begin{array}{c}\text { Age } 7 \text { to } 9-\text { Log PIAT } \\
\text { Score }\end{array}$} \\
\hline & Coeff & s.e. & Coeff & s.e. & Coeff & s.e. & Coeff & s.e. \\
\hline Intercept & -3.534 & 5.962 & 0.023 & 0.272 & 1.118 & 7.112 & 0.176 & 0.188 \\
\hline BLACK & -1.184 & 0.809 & -0.060 & 0.037 & -0.667 & 1.022 & -0.028 & 0.027 \\
\hline FEMALE & $1.310^{* *}$ & 0.654 & -0.018 & 0.030 & $1.580^{*}$ & 0.846 & 0.017 & 0.022 \\
\hline $\begin{array}{l}\text { FEMALE } x \\
\text { BLACK }\end{array}$ & -1.151 & 1.032 & -0.001 & 0.047 & -1.099 & 1.272 & -0.005 & 0.034 \\
\hline CHILD AGE & $0.698 * * *$ & 0.205 & $0.027 * * *$ & 0.009 & 0.390 & 0.242 & 0.007 & 0.006 \\
\hline NUMSIBS & 0.063 & 0.457 & 0.022 & 0.021 & 0.421 & 0.617 & 0.002 & 0.016 \\
\hline $\begin{array}{l}\text { FAMILY } \\
\text { INCOME }\end{array}$ & -0.001 & 0.012 & $-0.001 * *$ & 0.001 & -0.003 & 0.014 & -0.000 & 0.000 \\
\hline $\begin{array}{l}\text { MISSING } \\
\text { INCOME }\end{array}$ & 0.077 & 1.018 & -0.023 & 0.047 & -0.670 & 1.213 & -0.015 & 0.032 \\
\hline PCTMAR & -0.274 & 0.867 & -0.024 & 0.040 & 1.109 & 1.081 & 0.013 & 0.029 \\
\hline PCTDIV & 0.228 & 0.864 & -0.003 & 0.039 & -0.507 & 1.049 & -0.020 & 0.028 \\
\hline MLFP & $2.634^{*}$ & 1.576 & 0.005 & 0.072 & $3.770^{*}$ & 1.937 & 0.035 & 0.051 \\
\hline MHRS & 0.019 & 0.025 & $0.003 * * *$ & 0.001 & 0.010 & 0.032 & 0.000 & 0.001 \\
\hline MLFP $x$ MHRS & $-0.078^{*}$ & 0.046 & -0.003 & 0.002 & -0.082 & 0.057 & -0.001 & 0.002 \\
\hline PCTAFDC & $-1.628^{*}$ & 0.983 & 0.058 & 0.045 & 0.639 & 1.188 & $0.054^{*}$ & 0.031 \\
\hline $\begin{array}{l}\text { MOTHER'S } \\
\text { EDUCATION }\end{array}$ & -0.487 & 0.498 & -0.037 & 0.023 & 0.686 & 0.895 & 0.003 & 0.024 \\
\hline $\begin{array}{l}\text { PRESENCE OF } \\
\text { MEDICAL } \\
\text { CONDITION }\end{array}$ & 0.377 & 0.500 & $0.041^{*}$ & 0.023 & 0.678 & 0.569 & $0.026^{*}$ & 0.015 \\
\hline YEAR90 & 0.911 & 1.125 & $0.102 * *$ & 0.051 & 1.916 & 1.318 & 0.045 & 0.035 \\
\hline YEAR92 & 2.210 & 1.383 & $0.157^{* *}$ & 0.063 & 1.413 & 1.605 & 0.038 & 0.043 \\
\hline Adj. $\mathbf{R}^{2}$ & 0.048 & & 0.029 & & 0.014 & & -0.005 & \\
\hline Observations & 812 & & 812 & & 651 & & 651 & \\
\hline
\end{tabular}

*** Significant at $1 \%$ level, **5\% level, *10\% level. 


\begin{tabular}{|c|c|c|c|c|c|}
\hline \multirow[b]{2}{*}{ Variable Name } & \multirow[b]{2}{*}{ Description } & \multicolumn{2}{|c|}{ Age 7} & \multicolumn{2}{|c|}{ Age 9} \\
\hline & & Mean & S.D. & Mean & S.D \\
\hline READ & Raw score for PIAT reading recognition test & 29.733 & 9.047 & 42.771 & 11.513 \\
\hline MATH & Raw score for PLAT math achievement test & 26.919 & 8.890 & 40.082 & 9.519 \\
\hline BLACK & Dichotomous: one if black & 0.401 & 0.490 & 0.449 & 0.498 \\
\hline FEMALE & Dichotomous: one if female & 0.496 & 0.500 & 0.518 & 0.500 \\
\hline AGE & Age in months & 91.017 & 4.681 & 114.707 & 4.376 \\
\hline PCTMAR & Percent of time between child assessments in which mother was married & 0.571 & 0.473 & 0.553 & 0.476 \\
\hline PCTDIV & Percent of time between child assessments in which mother was divorced/separated & 0.222 & 0.392 & 0.240 & 0.405 \\
\hline NUMSIBS & Number of siblings & 2.427 & 1.053 & 2.565 & 1.134 \\
\hline MLFP & Percent of weeks between child assessments in which mother was in labor market & 0.558 & 0.404 & 0.577 & 0.400 \\
\hline MHRS & Average number of hours worked per week by mother between child assessments & 28.196 & 17.802 & 28.469 & 17.650 \\
\hline MOMEDUC & Mother's education & 12.147 & 1.922 & 11.959 & 1.786 \\
\hline MOMAGE & Mother's age & 29.288 & 2.637 & 29.902 & 2.374 \\
\hline PCTAFDC & Percent of time between child assessments that family was on AFDC & 0.178 & 0.348 & 0.192 & 0.355 \\
\hline $\begin{array}{l}\text { POOR } \\
\text { HEALTH }\end{array}$ & $\begin{array}{l}\text { Dichotomous: One if child has a condition which limits play or requires medical } \\
\text { attention }\end{array}$ & 0.072 & 0.259 & 0.095 & 0.294 \\
\hline WEIGHT10 & Dichotomous: One if child's weight is below the 10 th percentile for gender & 0.067 & 0.251 & 0.079 & 0.270 \\
\hline WEIGHT25 & Dichotomous: One if child's weight is below the 25 th percentile for gender & 0.189 & 0.391 & 0.155 & 0.363 \\
\hline HEIGHT10 & Dichotomous: One if child's height is below 10th percentile for gender & 0.121 & 0.327 & 0.103 & 0.304 \\
\hline HEIGHT25 & Dichotomous: One if child's height is below 25th percentile for gender & 0.204 & 0.403 & 0.180 & 0.385 \\
\hline BMI10 & Dichotomous: One if child's body mass index is below 10th percentile for gender & 0.157 & 0.364 & 0.107 & 0.309 \\
\hline BM125 & Dichotomous: One if child's body mass index is below 25 th percentile for gender & 0.241 & 0.428 & 0.202 & 0.402 \\
\hline NUMILL & Number of illnesses in the past year that required medical attention & 0.706 & 1.422 & 0.595 & 1.257 \\
\hline SERILL & $\begin{array}{l}\text { Dichotomous: One if child has any serious health condition - asthma, respiratory } \\
\text { disorder, orthopedic handicap, heart trouble, chronic nervous disorder }\end{array}$ & 0.031 & 0.172 & 0.047 & 0.212 \\
\hline BIRTHW & Birthweight in ounces & 116.153 & 20.023 & 115.141 & 20.383 \\
\hline $\begin{array}{l}\text { FAMILY } \\
\text { INCOME }\end{array}$ & Three (two) year average real family income in thousands & 18.749 & 22.817 & 18.868 & 24.192 \\
\hline $\begin{array}{l}\text { MISSING } \\
\text { INCOME }\end{array}$ & Dichotomous: One if average family income is missing in two of last three years & 0.073 & 0.260 & 0.082 & 0.275 \\
\hline CRIME & Crime rate per 100 persons in county of residence & 4.944 & 2.536 & 4.984 & 2.567 \\
\hline PCTFHEAD & Percentage of families with female head of household in county of residence & 14.500 & 5.186 & 14.615 & 5.295 \\
\hline PCAPINC & Real Income per capita in thousands in county of residence & 9.538 & 2.069 & 9.477 & 2.093 \\
\hline YEAR90 & Dichotomous: One if observation is from 1988 and 1990 surveys & 0.297 & 0.457 & 0.345 & 0.476 \\
\hline YEAR92 & Dichotomous: One if observation is from 1990 and 1992 surveys & 0.346 & 0.476 & 0.377 & 0.485 \\
\hline OBS & Number of observations & 848 & & 682 & \\
\hline
\end{tabular}

